\title{
Mitochondrial patterns of intra- and interspecific differentiation among endemic freshwater crabs of ancient lakes in Sulawesi
}

\author{
Christoph D. Schubart, Tobias Santl, Peter Koller \\ Biologie I, Universität Regensburg, 93040 Regensburg, Germany, Christoph.Schubart@biologie.uni-regensburg.de
}

Key words: species flock, adaptive radiation, ecotypes, morphotypes, genetic barcoding, Cox1 mtDNA

\begin{abstract}
Due to their long-term ecological stability, ancient lakes represent very interesting systems for studying differentiation and speciation processes. High degrees of endemism and specialisation are characteristic features of their fauna. The Malili lakes from the Indonesian island Sulawesi are considered an ancient limnic system, and recent research has increased the number of recognized species and the knowledge about ecological and morphological diversification within a variety of animal taxa. Here we show that the local endemic gecarcinucid freshwater crabs are more differentiated than qualitative morphological characters and the current taxonomy may indicate. The morphologically and ecologically well characterised species Nautilothelphusa zimmeri Balss, 1933 consists of two allopatric populations with one of the groups being more closely related to sympatric Parathelphusa ferruginea Chia and $\mathrm{Ng}, 2006$ according to mitochondrial genetic data. One haplotype is even shared by both species. Nevertheless, in this study lack of gene flow between both species is demonstrated. To our knowledge, this is the first report of DNA sequence identity between two different genera along the same cytochrome oxidase I gene segment that is being proposed for barcoding studies.
\end{abstract}

\section{Contents}

Introduction 83

Material and Methods ………........................................... 84

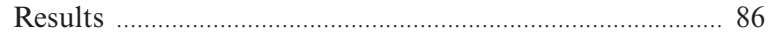

Discussion ........................................................................... 87

Acknowledgments ………............................................. 89

References ................................................................ 89

\section{Introduction}

On the Indonesian island of Sulawesi, formerly known as Celebes, two unconnected systems of ancient lakes, i. e. Lake Poso and the Malili lake system, harbour several endemic species and species flocks that apparently evolved as a consequence of adaptive radiation (von Rintelen et al., 2004; Roy et al., 2004, 2007; Herder et al., 2006). The Malili lake system consists of the three major lakes, Matano, Mahalona and Towuti, and two additional smaller ones. Overall, the water of these lakes is clear and oligotroph with very limited biological production (Haffner et al., 2006). Lake Matano is especially remarkable by being a graben lake of approximately $590 \mathrm{~m}$ depth (Haffner et al., 2001) with an age of about 2-4 Myr (Brooks, 1959; Hamilton, 1997).

A variety of animal taxa evolved species flocks within the Malili lake system, e. g. gastropods (von Rintelen et al., 2004), fish (Roy et al., 2004, 2007; Herder et al., 2006) and shrimps (von Rintelen et al., in preparation), of which the phylogenetic relationships and adaptive radiations are being studied. Within the lakes, there are also at least five endemic species of freshwater crabs (Chia and Ng, 2006) belonging to three different ecotypes (Schubart and Koller, 2006; Schubart and $\mathrm{Ng}$, in press). The latter authors have shown that both Lake Poso and the Malili lake system have been colonized independently at least twice. Part of the ecological and taxonomic diversity of these crabs can thus not be the consequence of a single adaptive radiation. The previous studies also showed that two species of freshwater crabs from the Malili lakes, namely Parathelphusa ferruginea and Nautilothelphusa zimmeri (from lakes Matano and Mahalona), share identical haplotypes of the mitochondrial 16S rRNA gene. In contrast, the Lake Matano population of $N$. zimmeri forms the outgroup to this clade of sympatrically occurring populations of $N$. zimmeri and $P$. ferruginea from lakes Mahalona and Towuti, despite the fact, that the monotypic genus Nautilothelphusa appears morphologically and ecologically well characterised and differentiated. 
The aim of the present study was to investigate the phylogenetic mitochondrial history of Nautilothephusa zimmeri and Parathelphusa ferruginea with more detail. A more variable genetic marker and a larger sample size was therefore used to help distinguish consistently between representatives of both species in Lake Mahalona and Lake Towuti and to test, whether $P$. ferruginea mtDNA maintains its intermediate phylogenetic position between two populations of $N$. zimmeri, or whether this pattern would change with a better resolved phylogeny. Compared to the previous qualitative work, the larger sample size of this study allows application of quantitative population genetic methods in order to determine whether there is ongoing gene flow among the sympatric species.

\section{Material and Methods}

Between 2000 and 2004, 71 specimens of freshwater crabs (Brachyura: Gecarcinucidae, see Klaus et al., 2006) were collected from 24 sampling points (Fig. 1) from the Indonesian island of Sulawesi.
Most of the specimens were collected from the Malili lakes (Table 1). The specimens were preserved and stored in ethanol (75-99\%). In addition, tissue was obtained from museum collections of the Raffles Museum Zoological Reference Collection Singapore (ZRC) and the Museum für Naturkunde Berlin (ZMB).

We amplified and sequenced 658bp of the cytochrome oxidase I (Cox1) gene from 30 specimens of Nautilothelphusa zimmeri (10 from Lake Matano, 8 from Lake Mahalona and 12 from Lake Towuti), 24 specimens of Parathelphusa ferruginea ( 6 from Lake Mahalona, 16 from Lake Towuti and 2 from tributaries to Lake Towuti), six of Parathelphusa pantherina (Schenkel, 1902) from Lake Matano, two of Syntripsa matannensis (Schenkel, 1902) from Lake Matano, and three of Syntripsa flavichela Chia and $\mathrm{Ng} 2006$ from Lake Mahalona and Lake Towuti. As river species, we included two specimens of Parathelphusa pallida (Schenkel, 1902) and one specimen each of Parathelphusa possoensis (Roux, 1904), Parathelphusa sarasinorum (Schenkel, 1902), Parathelphusa celebensis (de Man, 1892) and Parathelphusa lokaensis (de Man, 1892). Among those, P. lokaen-

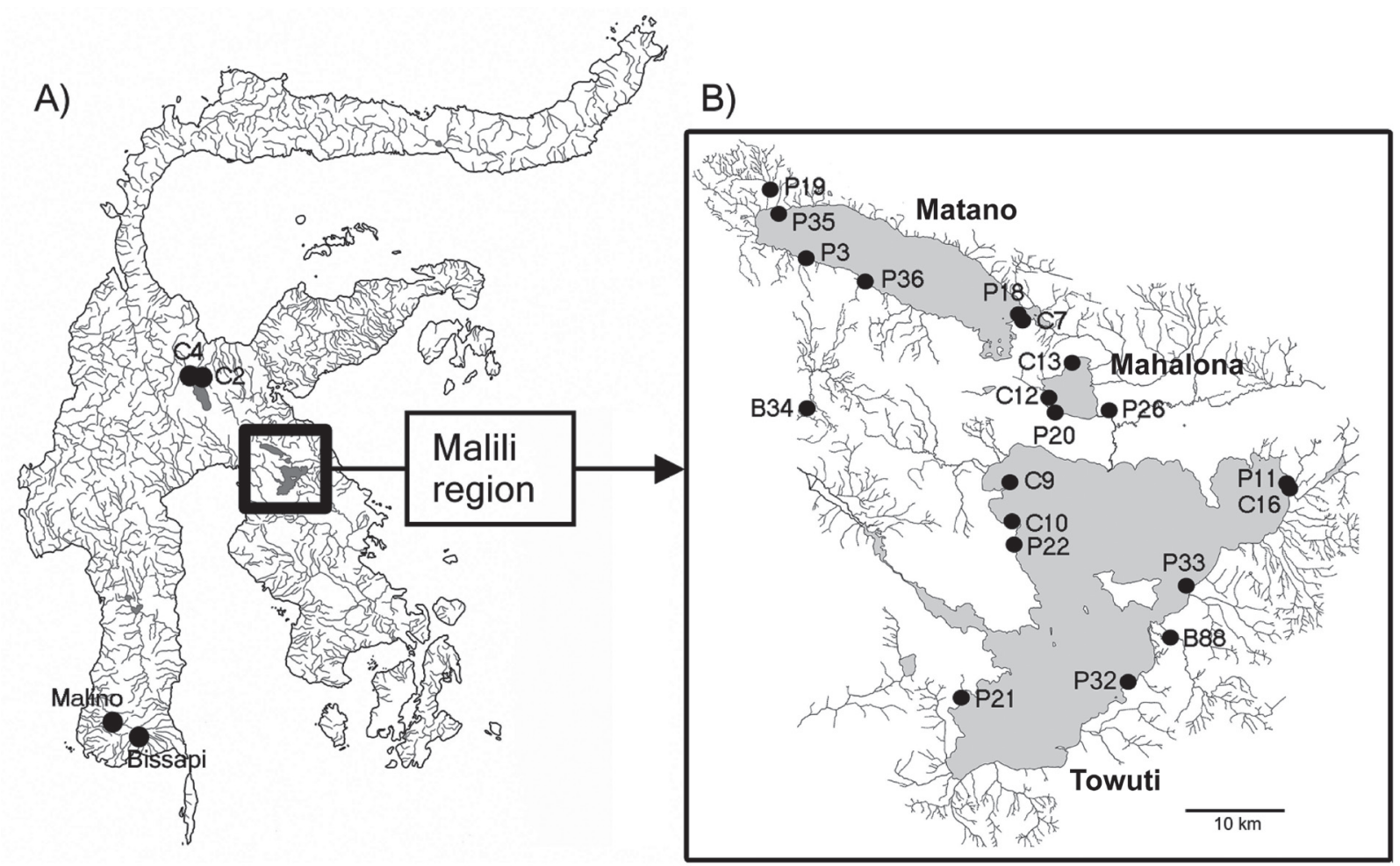

Fig. 1. Maps with the location of the freshwater-crab sampling points: A) The island of Sulawesi, B) the Malili region (modified from von Rintelen and Glaubrecht, 2005). 
sis is the only Sulawesi freshwater crab species not occurring within the Malili region and was used as an outgroup, because it may share a relatively recent common ancestor with the fauna from and around the lakes.

DNA was extracted from leg muscle tissue with the Puregene method (Gentra Systems) and used for polymerase chain reactions (PCR) with the primers LCO 1490 (GGT CAA CAA ATC ATA AGA TAT TGG) (Folmer et al., 1994), COL6b (ACA AAT CAT AAA GAT ATY GG) and COH6 (TAD ACT TCD GGR TGD CCA AAR AAY CA) (Schubart and Huber, 2006). PCRs were carried out with the following profile: 40 cycles with 45 $\sec 94^{\circ} \mathrm{C}, 1 \mathrm{~min} 48-50^{\circ} \mathrm{C}$ and $1 \mathrm{~min} 72^{\circ} \mathrm{C}$ for denaturing, annealing and extension respectively. PCR products were purified with the Quick-Clean kit (Bioline) or Microcon filters (Millipore), cycle sequenced with the Big Dye Terminator v1.1 (AB Applied Biosystems) and analysed with the automated capillary DNA sequencer ABI PRISM ${ }^{\circledR} 310$ Genetic Analyzer (Applied Biosystems). Sequences of all haplotypes have been submitted to the European Molecular Biology Laboratories (EMBL) and are accessible under FM 177599 - FM 177643.

Alignment of the sequences was carried out with the program BioEdit (Hall, 1999). Absence of insertions/deletions and stop codons suggested lack of nuclear copies and resulted in one obvious alignment. The aligned sequences were analyzed for the best fitting model of DNA evolution with the software Modeltest 3.6 (Posada and Crandall, 1998). The resulting model of evolution $\mathrm{GTR}+\mathrm{I}+\mathrm{G}$ with the corresponding parameters $($ gamma $=0.871$; $\mathrm{I}=$ 0.523 ) was used for Minimum Evolution (ME) and Bayesian Inference (BI) analyses. We used three different methods of phylogenetic inference for our dataset, Maximum Pasimony (MP) and Minimum Evolution (ME) using the software package PAUP* 4.0 (Swofford, 2001) and the Bayesian analysis (BI) using MrBayes v.3.0b4 (Huelsenbeck and Ronquist, 2001). MP trees were calculated with a heuristic search. Confidence values for the different groups within the trees were calculated with the bootstrap method (2,000 pseudoreplicates). Starting trees were obtained by stepwise random sequence addition with ten repetitions and five trees held per step. Branch swapping was conducted with the tree-bisection-

Table 1. List of sampling points from which freshwater crabs were collected in Sulawesi

\begin{tabular}{|c|c|c|c|c|}
\hline \multicolumn{2}{|c|}{ Sampling point } & Location & Species \& number of specimens & Museum collection \\
\hline B34 & non-tributary river & $2^{\circ} 36.53^{\prime} \mathrm{S}, 121^{\circ} 15.56^{\prime} \mathrm{E}$ & 1 P. pallida & ZMB \\
\hline$\overline{\mathrm{B} 88}$ & tributary to L. Towuti & $2^{\circ} 48.93^{\prime} \mathrm{S}, 121^{\circ} 35.01^{\prime} \mathrm{E}$ & 1 P. ferruginea & ZMB \\
\hline$\overline{\mathrm{C} 2}$ & Tentena at L. Poso & $01^{\circ} 45^{\prime} 44.4^{\prime \prime} \mathrm{S}, 120^{\circ} 38^{\prime} 21.5^{\prime \prime} \mathrm{E}$ & 1 P.sarasinorum & ZRC \\
\hline$\overline{\mathrm{C}} 4$ & tributary to L. Poso & $01^{\circ} 45^{\prime} 0.9^{\prime \prime} \mathrm{S}, 120^{\circ} 32^{\prime} 19.9{ }^{\prime \prime} \mathrm{E}$ & 1 P.possoensis & ZRC \\
\hline$\overline{\mathrm{C} 7}$ & east Matano & $02^{\circ} 31^{\prime} 48.7^{\prime \prime} \mathrm{S}, 121^{\circ} 27^{\prime} 9.99^{\prime \prime} \mathrm{E}$ & $1 \mathrm{~N}$. zimmeri & ZRC \\
\hline $\mathrm{C9}$ & northwest Towuti & $02^{\circ} 40^{\prime} 37.7^{\prime \prime} \mathrm{S}, 121^{\circ} 26^{\prime} 26.0^{\prime \prime} \mathrm{E}$ & $1 \mathrm{~N}$. zimmeri & ZRC \\
\hline $\mathrm{C} 10$ & northwest Towuti & $02^{\circ} 42^{\prime} 37.7^{\prime \prime} \mathrm{S}, 121^{\circ} 26{ }^{\prime} 26.0^{\prime \prime} \mathrm{E}$ & 2 P. ferruginea & ZRC \\
\hline $\mathrm{C} 12$ & west Mahalona & $02^{\circ} 35^{\prime} 57.2^{\prime \prime} \mathrm{S}, 121^{\circ} 28^{\prime} 19.2^{\prime \prime} \mathrm{E}$ & $1 N$. zimmeri & ZRC \\
\hline $\mathrm{C} 13$ & north Mahalona & $02^{\circ} 33 ' 54.33^{\prime} \mathrm{S}, 121^{\circ} 29^{\prime} 44.1^{\prime \prime} \mathrm{E}$ & 1 P. ferruginea & ZRC \\
\hline $\mathrm{C} 16$ & northeast Towuti & $02^{\circ} 40.89^{\prime} \mathrm{S}, 121^{\circ} 41.49^{\prime} \mathrm{E}$ & 1 P. ferruginea & ZRC \\
\hline$\overline{\mathrm{P} 3}$ & south Matano & $02^{\circ} 33.566^{\prime} \mathrm{S}, 121^{\circ} 25.187^{\prime} \mathrm{E}$ & $\begin{array}{l}4 \text { N. zimmeri, } 1 \text { P. pantherina, } \\
1 \text { S. matannensis }\end{array}$ & ZMB \\
\hline$\overline{\mathrm{P} 11}$ & northeast Towuti & $02^{\circ} 40.82^{\prime} \mathrm{S}, 121^{\circ} 41.43^{\prime} \mathrm{E}$ & $\begin{array}{l}1 \mathrm{~N} \text {. zimmeri, } 3 \text { P. ferruginea, } \\
1 \mathrm{~S} \text {. flavichela }\end{array}$ & ZMB \\
\hline$\overline{\mathrm{P} 18}$ & east Matano & $02^{\circ} 31.492^{\prime} \mathrm{S}, 121^{\circ} 26.996^{\prime} \mathrm{E}$ & $\begin{array}{l}5 \text { N. zimmeri, } 2 \text { P. pantherina, } \\
1 \text { S. matannensis }\end{array}$ & ZMB \\
\hline P19 & tributary to L. Matano & $02^{\circ} 24.932^{\prime} \mathrm{S}, 121^{\circ} 13.594^{\prime} \mathrm{E}$ & 1 P. pallida & ZMB \\
\hline $\mathrm{P} 20$ & southwest Mahalona & $02^{\circ} 36.64^{\prime} \mathrm{S}, 121^{\circ} 28.54^{\prime} \mathrm{E}$ & 7 N. zimmeri, 2 S. flavichela & ZMB \\
\hline$\overline{\mathrm{P} 21}$ & southwest Towuti & $02^{\circ} 51.732^{\prime} \mathrm{S}, 121^{\circ} 23.907^{\prime} \mathrm{E}$ & $3 N$. zimmeri, 1 P. ferruginea & ZMB \\
\hline P22 & west Towuti & $02^{\circ} 43.696^{\prime} \mathrm{S}, 121^{\circ} 26.360^{\prime} \mathrm{E}$ & 2 N. zimmeri & ZMB \\
\hline$\overline{\mathrm{P} 26}$ & Tominanga River & $02^{\circ} 36.638^{\prime} \mathrm{S}, 121^{\circ} 31.822^{\prime} \mathrm{E}$ & 1 P. ferruginea & ZMB \\
\hline$\overline{\mathrm{P} 32}$ & southeast Towuti & $02^{\circ} 51.38^{\prime} \mathrm{S}, 121^{\circ} 32.73^{\prime} \mathrm{E}$ & $2 N$. zimmeri, 5 P. ferruginea & ZMB \\
\hline $\mathrm{P} 33$ & east Towuti & $02^{\circ} 46.20^{\prime} \mathrm{S}, 121^{\circ} 35.97^{\prime} \mathrm{E}$ & $3 N$. zimmeri, 4 P. ferruginea & ZMB \\
\hline P35 & northwest Matano & 2025’56.20”S, 121 14'19.91”E & 2 P. pantherina & ZMB \\
\hline$\overline{\mathrm{P} 36}$ & south Matano & $2^{\circ} 29^{\prime} 38.06^{\prime \prime S}, 121^{\circ} 18^{\prime} 30.47^{\prime \prime} \mathrm{E}$ & 1 P. pantherina & ZMB \\
\hline unspecified: & L. Mahalona & unknown & 5 P. ferruginea & \\
\hline Bissapi & South Sulawesi & 5²6'46.96"S, 11958'7.17"E & P. celebensis & ZMB \\
\hline Malino & South Sulawesi & $5^{\circ} 15^{\prime} 43.74 ” \mathrm{~S}, 119^{\circ} 44^{\prime} 56.63$ 'E & P. lokaensis & ZMB \\
\hline
\end{tabular}


reconnection (TBR) algorithm, holding multiple trees (MulTrees). Maximum number of trees was set to 5,000 ( $\max$ trees). Otherwise, the default options of PAUP* 4.0 were used. Only minimal trees were retained and zero length branches were collapsed. The Bayesian analysis was run with four MCMC chains for 2,000,000 generations, saving a tree every 500 generations. After excluding a burnin phase of 20,000 generations with possible random and suboptimal trees, the posterior probabilities of the phylogeny were determined for the remaining trees. Consensus trees were constructed using the 'sumt' option of MrBayes. As a measure of genetic differentiation between taxa, the $\Phi_{\mathrm{ST}}$ value was calculated with an AMOVA (Excoffier et al. 1992) using the software Arlequin ver. 3.0 (Excoffier et al., 2005).

\section{Results}

The analyses of sequence data of 658 basepairs of the cytochrome oxidase I gene from 71 specimens supports the idea that the freshwater crab species occurring in the Malili lakes do not originate from one single common ancestor (Fig. 2).

One lineage (cluster I) contains the generalist and detritivore ecotypes of the lakes, Parathelphusa pantherina, Parathelphusa ferruginea and Nautilothelphusa zimmeri, and forms a well-supported clade in the analyses (BI 0.98; MP 76; ME 69). The molluscivore species Syntripsa matannensis and Syntripsa flavichela comprise the other lineage (cluster II; BI 1.0; MP 100; ME 100), which does not represent the sister clade to cluster I. Instead, the phylogenetic relationship of cluster II is either unresolved, as in the case of the MP and ME analyses (Fig. 2), or it groups together with the well-supported group (BI 0.92; MP 97; ME 95) of Parathelphusa possoensis and Parathelphusa sarasinorum from Lake Poso and tributaries in the BI (confidence of 0.85 not shown). Cluster I represents a sister taxon to Parathelphusa pallida, a riverine freshwater crab occurring in the Malili region (BI 0.97; MP 59; ME 65). The phylogenetic position of Parathelphusa celebensis, another riverine species from the south of Sulawesi, is very basal and clearly separated from the Malili lakes species.

Within the Malili lakes lineages, the phylogenetic pattern reported previously could be confirmed (Schubart and $\mathrm{Ng}$, in press). The homogeneity of $P$.

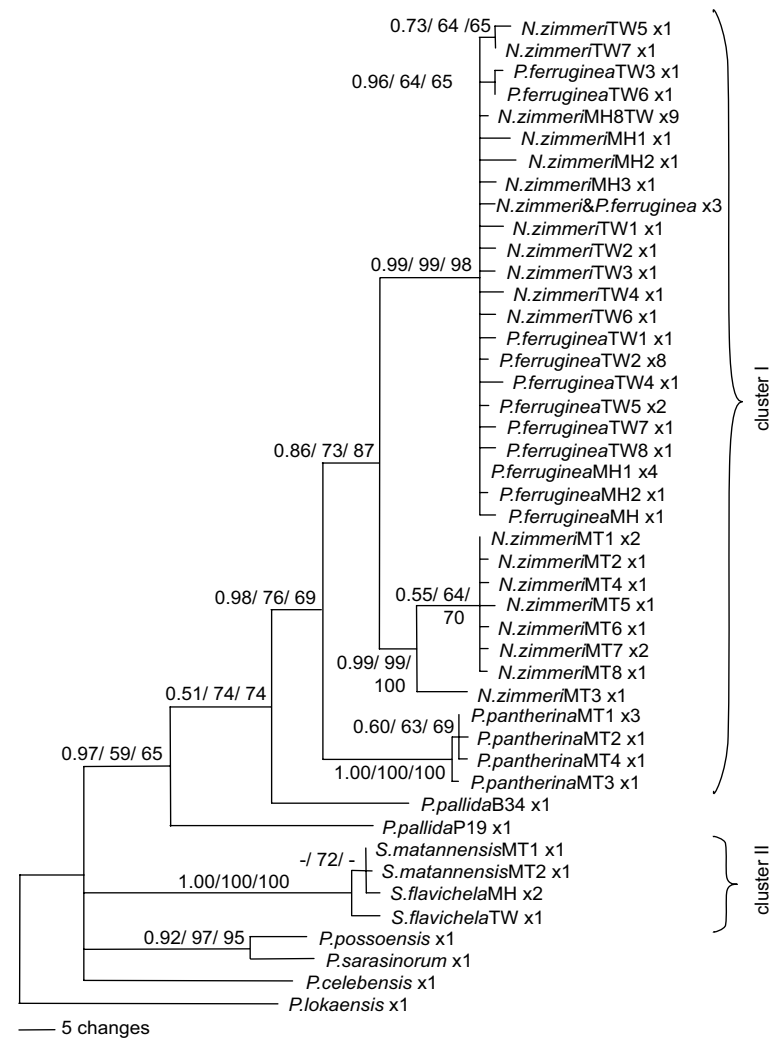

Fig. 2. Bootstrap 50\% majority-rule consensus tree (MP topology) of phylogenetic relationships of the freshwater crab species from the Malili lake system (Parathelphusa pantherina, P. ferruginea, Nautilothelphusa zimmeri, Syntripsa matannensis and $S$. flavichela), also including $P$. sarasinorum from Lake Poso and the river species $P$. pallida, P. celebensis, $P$. possoensis and the outgroup P. lokaensis. Bayesian Inference, Maximum Parsimony and Minimum Evolution topologies with $\mathrm{GTR}+\mathrm{I}+\mathrm{G}$ model of evolution where applicable. Confidence values from 2,000 bootstrap replicates (MP/ME) or posterior probabilities (BI) based on 658 basepairs of the Cox1 gene (only values above 50/0.5 shown). MT: Lake Matano; MH: Lake Mahalona; TW: Lake Towuti. Letters behind locality identify haplotype names; ' $x$ ' numbers behind taxa reflect the frequency of the corresponding haplotype in the sample.

pantherina, the generalist from Lake Matano, is very well supported by our results (BI 1.0; MP 100; ME 100) and this species forms the sister taxon to the cluster of all P. ferruginea and N. zimmeri (BI 0.86; MP 73; ME 87). Within the latter cluster, the generalist $P$. ferruginea (from Lake Mahalona and Lake Towuti) groups together with the sympatric population of N. zimmeri (BI 0.99; MP 99; ME 98), whereas the Matano population of $N$. zimmeri is well separated from the first group (BI 0.99; MP 99; 


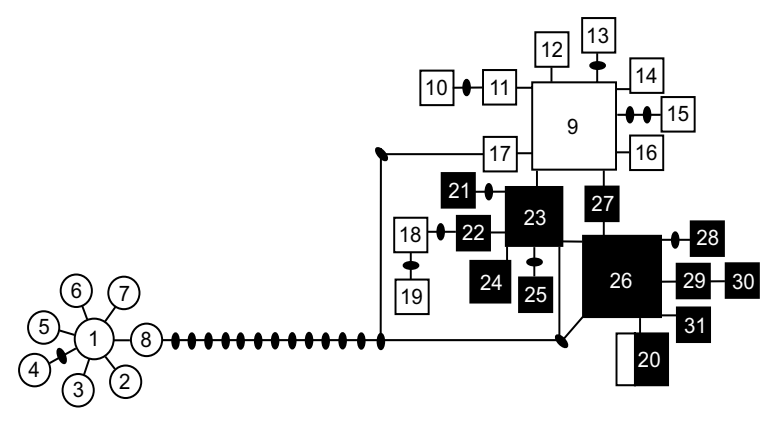

Fig. 3. Minimum parsimonious spanning network of N. zimmeri and $P$. ferruginea of a $658 \mathrm{bp}$ fragment from the Cox 1 gene. Each line represents one substitution; missing haplotypes are represented by black ovals. The size of a circle or square is representative for the frequency of the haplotype $(\mathrm{N}=1-9)$. Circles correspond to Lake Matano, squares to Lake Mahalona \& Lake Towuti; white circles and squares correspond to $N$. zimmeri, black squares to $P$. ferruginea; haplotype 20 was shared by one $N$. zimmeri specimen and two P. ferruginea specimens.

ME 100) (Fig. 2). In the minimum spanning network, $N$. zimmeri from Lake Matano is separated from the conspecific population in lakes Mahalona and Towuti and from $P$. ferruginea by at least 13 mutational steps (Fig. 3).

Within the cluster of the generalist ( $P$. ferruginea morph) and the detritivore ( $N$. zimmeri morph) forms from lakes Mahalona and Towuti, a weak separation of the two species can be observed, but not very distinct and consistent. Three haplotypes of $N$. zimmeri $(18,19,20)$ are positioned within the $P$. ferruginea cluster, one of them is even shared by both species (Fig. 3). The pairwise $\Phi_{\mathrm{ST}}$ value of 0.057 between the two species is low, yet highly significant $(\mathrm{p}<0.001)$, indicating a restriction of gene flow, but maybe very recent or incomplete. In comparison to that, the $\Phi_{\mathrm{ST}}$ value between the Matano population and the Mahalona/Towuti population of $N$. zimmeri is much higher $\left(\Phi_{\mathrm{ST}}=0.462 ; \mathrm{p}<0.001\right)$. This finding is surprising, since morpholgically and ecologically the two populations of $N$. zimmeri are very similar and clearly derived from the bodyplan of riverine species and those of lacustrine generalists as $P$. ferruginea.

\section{Discussion}

Our genetic results render additional support to the previous finding that the extant freshwater crab species from the Malili lake system did not evolve from one single ancestor (see also Schubart and $\mathrm{Ng}$, in press). There were at least two separate colonization events, resulting in two not directly related clusters, i.e. cluster I ( Parathelphusa pantherina, Parathelphusa ferruginea \& Nautilothelphusa zimmeri) and cluster II (Syntripsa matannensis \& Syntripsa flavichela) (Fig. 2). These two groups do not only differ genetically, but are also ecologically separated, as the species of cluster I comprise the generalist ( $P$. pantherina, $P$. ferruginea) and the detritvore ( $N$. zimmeri) ecotypes, whereas the genus Syntripsa of cluster II appears to be molluscivorous judging by the chelar morphology (Chia and Ng, 2006; Schubart and Ng, in press). In terms of morphology and behaviour, the generalists are closest to the riverine forms and are therefore considered as the most underived ecotype in the lakes, with the detritivore (feeding on detritus and other small food items) and the molluscivore (specialized in feeding on hard-shelled molluscs) ecotypes being specialized to lake habitats (Chia and Ng, 2006). For the genus Syntripsa we could not detect a closely related sister taxon among the adjacent river populations. As no molluscivore riverine species is known, we also assume for this group a generalist ancestor, specializing on the abundant snails encountered in the lakes as a food source. The extremely strong crushing chela of these crabs and the thicker shells of the snail species of the lakes in comparison to riverine species points to a coevolution of the molluscivore crabs and the molluscs in an arms race (von Rintelen et al., 2004).

With the cytochrome oxidase I gene sequence data, we could confirm and expand the 16S rRNA based results of Schubart and $\mathrm{Ng}$ (in press). The Matano population of $N$. zimmeri forms an outgroup to the cluster of $P$. ferruginea and $N$. zimmeri from the lakes Mahalona and Towuti (Fig. 2), which would make the latter species a paraphylum according to mtDNA, indicating that either this generalist is derived from the detritivore type or that the detritivore ecotype evolved two times independently. This result is the more surprising as the populations of $N$. zimmeri are morphologically very similar with very characteristic features missing in $P$. ferruginea, e. g. the squarish carapace and the broadened propodi of the last pair of locomotory legs.

A qualitative separation of $P$. ferruginea and the sympatrically occurring $N$. zimmeri population was not possible with the analysed $658 \mathrm{bp}$ long fragment of the Cox1 gene. In the minimum spanning 
network (Fig. 3), some of the $N$. zimmeri haplotypes are positioned in between those from $P$. ferruginea and in one case a haplotype is even shared by two individuals of $P$. ferruginea and one individual of $N$. zimmeri. Howewer, here we show that these two groups differ significantly in their haplotype composition, which is indicated by a low, but highly significant $\Phi_{\mathrm{ST}}$ value $\left(\Phi_{\mathrm{ST}}=0.057, \mathrm{p}<0.001\right)$. A clearer separation may be possible with a more variable genetic marker or a longer fragment of the Cox1.

Although the results of mitochondrial genetic markers and morphology are in conflict with each other and data from nuclear genetic markers are still unavailable (Koller and Schubart, in progress), the two populations of $N$. zimmeri (Matano vs. other two lakes) differ genetically to a great extent and we can already claim lack of gene flow between them $\left(\Phi_{\mathrm{ST}}=0.462 ; \mathrm{p}<0.001\right)$. The question remains, whether these populations can be separated by morphological features. Separating qualitative morphological characters were not found during our investigations, but morphometric analyses are being carried out to distinguish between the two allopatric populations (Koller and Schubart, in progress).

Genetic distinction between the two populations of the detritivore $N$. zimmeri fits very well the finding that other crab ecotypes from the lakes are always represented by different species in Matano versus Mahalona/Towuti: P. pantherina, S. matannensis in Lake Matano and P. ferruginea, S. flavichela in the lakes Mahalona and Towuti. A similar pattern of consistent differences in species composition of these lakes can also be found in the endemic fish (Family Telmatherinidae) (Herder et al., 2006) and in atyid shrimps (genus Caridina) (Roy et al., 2006) of the Malili region. But in the case of the fish, all endemic species of Lake Matano originated from a single colonisation event, whereas for freshwater crabs, descendants of two colonisations can be found in all three major lakes. The viviparous freshwater gastropod genus Tylomelania also colonised the Malili lake sytem several times independently, but only one clade spread to all three major lakes, whereas the other two clades in this area are primarily restricted to the lake they colonised first (von Rintelen et al., 2004). Overall, ecological adaptions, i.e. trophic specialisation, are a general feature of speciation in the Malili lakes (see Roy et al., 2007), going along with potential others like sexual selection, alloparty or coevolution in the case of molluscs and snail-eating crabs.
Our results are also of importance with respect to the emerging field of barcoding animal life. Hebert et al. (2003) promoted the same Cox1 gene region as used in this study as the best marker for a DNA barcoding system to render fast and accurate taxonomic identification and aiding the discovery of new species. Such a species-specific barcode would be of great advantage for establishing and managing a taxonomic system of the animal kingdom, with a vast number of not yet described species. Moritz and Cicero (2004) pointed out possible limitations of mtDNA for recognizing species boundaries. Retention of ancestral polymorphism, male-biased gene flow, selection on any part of the mitochondrial genome, introgression and paralogy due to nuclear copies of the mitochondrial marker are factors that could produce phylogenetic signals of the mtDNA, which may deviate from the actual phylogeny of the species. Especially for closely related, young species and rapidly evolving lineages, problems in these regards have to be expected (Monaghan et al., 2006). In the case of Nautilothelphusa zimmeri and Parathelphusa ferruginea, species (and genus) identification by a Cox 1 barcode would be impossible. Due to the genetic identity of at least one haplotype, this Cox 1 region is not unique for any of the two species and therefore a genetic misidentification up to genus level would become possible. The genus Nautilothelphusa is closely related to Parathelphusa ferruginea. Thus, retention of Nautilothelphusa as a valid genus makes this a case of imperfect taxonomy (Meyer and Paulay, 2005) by making the genus Parathelphusa paraphyletic.

The here described pattern of shared haplotypes by two morphologically clearly divergent species and genera could possibly be explained by incomplete lineage sorting or introgression. Llopart et al. (2005) described for two West African species of Drosophila with a hybridization zone the genetic patterns of introgression, resulting in a situation in which the mitochondrial genome of one species was apparently completely replaced by the one from a second species. The importance of introgressive hybridization during invasion of new environments and speciation has been highlighted repeatedly (e.g. Dowling and Secor, 1997; Salzburger et al., 2002; Seehausen, 2004). Nuclear genetic data (in progress) may clarify, whether a similar case of introgression and mtDNA replacement has taken place in the crabs from Sulawesi and possibly provide independent evidence for other interesting aspects of this 
study, like the deep and complete genetic separation between the two populations of $N$. zimmeri from the different lakes.

\section{Acknowledgements}

We want to thank Fabian Herder (Forschungsmuseum Alexander Koenig, Bonn, Germany), Matthias Glaubrecht, Thomas and Kristina von Rintelen (Museum für Naturkunde, Berlin, Germany) for collecting specimens, organisation and support during the field trips and the exchange of ideas. The staff of INCO in Soroako, Lake Matano, kindly supported us by providing accommodation, transport and general logistics, which facilitated our field enormously. We are grateful for the continuous support by Peter K.L. Ng (National University of Singapore) and for identification of some of the river forms. Our thanks also go to Juergen Heinze (University of Regensburg) and his staff for the use of all the necessary facilities. Finally, we like to thank one anonymous reviewer for expert comments.

\section{References}

Balss H. 1933. Ueber einige systematisch interessante indopacifische Dekapoden. Mitteilungen aus dem Zoologischen Museum Berlin 19: 84-98.

Brooks JL. 1950. Speciation in ancient lakes concluded. Quarterly Review of Biology 25: 131-176.

Chia OKS, Ng PKL. 2006. The freshwater crabs of Sulawesi, with descriptions of two new genera and four new species (Crustacea: Decapoda: Brachyura: Parathelphusidae). Raffles Bulletin of Zoology 54: 381-428.

De Man JG 1892. Decapoden des Indischen Archipels. In: Weber, M, ed. Zoologische Ergebnisse einer Reise in Niederländisch Ostindien. Leyden, Netherlands, vol. 2, 265-527.

Dowling TE, Secor CL. 1997. The role of hybridization and introgression in the diversification of animals. Annual Review of Ecology and Systematics 28: 563-619.

Excoffier L, Laval G, Schneider S. 2005. Arlequin ver. 3.0: An integrated software package for population genetics data analysis. Evolution and Bioinformatics Online 1: 47-50.

Excoffier L, Smouse PE, Quattro JM. 1992. Analysis of Molecular Variance Inferred From Metric Distances Among DNA Haplotypes: Application to Human Mitochondrial DNA Restriction Data. Genetics 131: 479-491.

Folmer O, Black M, Hoeh W, Lutz R, Vrijenhoek R. 1994. DNA primers for amplification of mitochondrial cytochrome c oxidase subunit I from diverse metazoan invertebrates. Molecular Marine Biology and Biotechnology 3: 294-299.

Haffner GD, Sabo L, Bramburger A, Hamilton P, Hehanussa P. 2006. Limnology and sediment dynamics in the Malili Lakes: What regulates biological production? In: The Ecology and Limnology of the Malili Lakes. Hehanussa PE, Haryani GS and Ridwansyah I, eds. Proceedings International Symposium, Bogor, Indonesia 20-22 March
2006, page 5. LIPI Press, Jakarta, Indonesia. ISBN 979-26-2407-4.

Haffner GD, Hehanussa PE, Hartoto D. 2001. The biology and physical processes of large lakes of Indonesia: Lakes Matano and Towuti. In: Munavar, M, Hecky RE, eds. The great lakes of the world (GLOW): food-web, health and integrity. Backhuys Publishers, Leiden, Netherlands, 183-192.

Hall T. 1999. BioEdit: a user-friendly biological sequence alignment editor and analysis program for Windows95/98/ NT. Nucleic Acids Symposium Series 41: 95-98.

Hamilton W. 1979. Tectonics of the Indonesian region. Geological survey professional paper 1078. Washington, United States Government Printing Office.

Hebert PDN, Cywinska A, Ball SL, deWaard JR. 2003. Biological identifications through DNA barcodes. Proceedings of the Royal Society London B 270: 313-321.

Herder F, Nolte AW, Pfaender J, Schwarzer J, Hadiaty RK, Schliewen UK 2006. Adaptive radiation and hybridization in Wallace's Dreamponds: evidence from sailfin silversides in the Malili Lakes of Sulawesi. Proceedings of the Royal Society London B 273: 2209-2217.

Huelsenbeck JP, Ronquist F. 2001. MRBAYES: Bayesian inference of phylogenetic trees. Bioinformatics 17: 754-755.

Klaus S, Schubart CD, Brandis D. 2006. Phylogeny, biogeography and a new taxonomy for the Gecarcinucoidea Rathbun, 1904 (Decapoda: Brachyura). Organisms Diversity and Evolution 6(3): 199-217.

Llopart A, Lachaise D, Coyne JA. 2005. Multilocus analysis of introgression between two sympatric sister species of Drosophila: Drosophila yakuba and D. santomea. Genetics 171: 197-210.

Meyer CP, Paulay G. 2005. DNA barcoding: Error rates based on comprehensive sampling. PLOS Biology 3: 2229-2238.

Monaghan MT, Blake M, Pons J, Vogler AP. 2006. Beyond barcodes: complex DNA taxonomy of a South Pacific Island radiation. Proceedings of the Royal Society London B 273: 887-893.

Moritz C, Cicero C. 2004. DNA Barcoding: Promises and Pitfalls. Public Library of Science, Biology 2: 1529-1531.

Posada D, Crandall KA. 1998. MODELTEST: testing the model of DNA substitution. Bioinformatics 14: 817-818.

Rintelen T von, Glaubrecht M. 2005. Anatomy of an adaptive radiation: a unique reproductive strategy in the endemic freshwater gastropod Tylomelania (Cerithioidea: Pachychilidae) on Sulawesi, Indonesia and its biogeographical implications. Biological Journal of the Linnean Society 85: 513-542.

Rintelen T von, Wilson AB, Meyer A, Glaubrecht M. 2004. Escalation and trophic specialization drive adaptive radiation of freshwater gastropods in ancient lakes on Sulawesi, Indonesia. Proceedings of the Royal Society London B 271: 2541-2549.

Roux J. 1904. Decapodes d'eau douce Celebes (genres Caridina \& Potamon). Revue Suisse de Zoologie 12: 539-571.

Roy D, Docker MF, Hehanussa P, Heath DD, Haffner GD. 2004. Genetic and morphological data supporting the hypothesis of adaptive radiation in the endemic fish of Lake Matano. Journal of Evolutionary Biology 17: 1268-1276. 
Roy D, Kelly DW, Fransen CHJM, Heath DD, Haffner GD. 2006. Evidence of small-scale vicariance in $\mathrm{Ca}$ ridina lanceolata (Decapoda: Atyidae) from the Malili Lakes, Sulawesi. Evolutionary Ecology Research 8: 1087-1099.

Roy D, Paterson G, Hamilton PB, Heath DD, Haffner GD. 2007. Resource-based adaptive divergence of the freshwater fish Telmatherina from Lake Matano, Indonesia. Molecular Ecology 16: 35-48.

Salzburger W. 2002. Speciation via introgressive hybridization in east African cichlids? Molecular Ecology 11: 619-625.

Schenkel E. 1902. Beitrag zur Kenntnis der Dakapodenfauna von Celebes. Verhandlungen der Naturforschenden Gesellschaft Basel 13: 485-618, Pls. 7-13.

Schubart CD, Huber MGJ. 2006. Genetic comparisons of German populations of the stone crayfish, Austropotamobius torrentium (Crustacea: Astacidae). Bulletin Français de la Pêche et de la Pisciculture 380-381: 319-1028.
Schubart CD, Koller P. 2006. Multiple colonization of ancient lakes in Sulawesi by parathelphusid crabs (Crustacea: Brachyura). In: The Ecology and Limnology of the Malili Lakes. Hehanussa PE, Haryani GS and Ridwansyah I, eds. Proceedings International Symposium, Bogor, Indonesia 20-22 March 2006, pages 47-53. LIPI Press, Jakarta, Indonesia. ISBN 979-26-2407-4.

Schubart CD, Ng PKL. In press. A new molluscivore crab from Lake Poso confirms multiple colonisation of ancient lakes in Sulawesi by freshwater crabs (Decapoda: Brachyura). Zool. Journal of the Linnean Society.

Seehausen O. 2004. Hybridization and adaptive radiation. Trends in Ecology and Evolution 19: 198-207.

Swofford D. 2001. PAUP: Phylogenetic Analysis Using Parsimony (and other methods). Sinauer Associates, Sunderland, MA.

Received: 19 February 2008

Accepted: 20 June 2008 